\section{Aquaculture}

Vol.262, Issue 1, 14 February 2007, Pages 41-53

http://dx.doi.org/10.1016/j.aquaculture.2006.10.025

(c) 2006 Elsevier B.V. All rights reserved
Archimer, archive institutionnelle de l'Ifremer http://www.ifremer.fr/docelec/

\title{
Summer mortality of hatchery-produced Pacific oyster spat (Crassostrea gigas). I. Estimation of genetic parameters for survival and growth
}

\author{
Lionel Dégremont ${ }^{\mathrm{a},{ }^{*}}$, Bruno Ernande $^{\mathrm{b}}$, Edouard Bédier $^{\mathrm{c}}$, Pierre Boudry $^{\mathrm{a},{ }^{, *}}$ \\ a IFREMER, Laboratoire de Génétique et Pathologie, F-17390 La Tremblade, France \\ ${ }^{b}$ IFREMER, Laboratoire Ressources Halieutiques, Ifremer, F-14520 Port en Bessin, France \\ ${ }^{c}$ IFREMER, Laboratoire Laboratoire Environnement Ressources Morbihan Pays de Loire, Ifremer, F- \\ 56470 La Trinité, France \\ * Present address: Aquaculture Genetics and Breeding Technology Center, Virginia Institute of Marine \\ Science, College of William and Mary, 1208 Greate Road, Gloucester-Point VA23062-1346, U.S.A. \\ ** Corresponding author: Tel.: 33-5-46-76-26-30; Fax.: 33-5-46-76-26-11; pierre.boudry@ifremer.fr
}

\begin{abstract}
:
The multidisciplinary project "MOREST" aims to improve our understanding of causes of summer mortality in Crassostrea gigas juveniles in France and to reduce its impact on oyster production. As part of the MOREST project, 43 full-sib families nested within 17 half-sib families were produced, planted out and tested in 3 sites during summer 2001 to assess to what extent genetic variability exists for this trait. A strong genetic basis was found for survival as narrow-sense heritability estimates ranged from 0.47 to 1.08 , with higher values in sites where summer mortality was higher. Genetic correlations across sites were positive and very high for survival, indicating no genotype by environment interaction. In contrast, lower genetic variation was observed for growth in all sites. Finally, genetic correlations between growth and survival were low, in all sites. Selective breeding in a single site should therefore be an efficient means of improving survival in oysters less than one year old along the French Atlantic and Channel coastlines with only very limited effects on growth. As yield mostly depends on survival and growth, this approach should significantly improve harvestable yield. Possible reasons why a high genetic variance for survival appears to be maintained in wild populations are discussed.
\end{abstract}

Keywords: Crassostrea gigas; Heritability; Juveniles; Survival; Growth 


\section{Introduction}

World oyster production was estimated at around 4.3 million metric tons in 2002 with a value of $\$ 3.5$ billion. The Pacific oyster, Crassostrea gigas, is one of the most important oysters cultured worldwide (FAO 2004a,b). This species has been extensively (both accidentally and intentionally) transported beyond its native oriental range (for review, see Shatkin et al., 1997). In France, C. gigas was introduced in the early 1970s (Grizel and Héral 1991) after the collapse in production of the Portuguese oyster (C. angulata) due to massive mortality events (Comps et al., 1976; Comps, 1983; Héral, 1989). In 2002, French oyster production represented 107,000 metric tons at a value of \$210 million (FAO, 2004a,b).

Summer mortality of C. gigas has been reported for many years in Japan and the United States (Koganezawa, 1975; Glude, 1975). It was first reported in France in the early 1980s by Maurer and Comps (1986) and by Bodoy et al. (1990) who observed mass summer mortalities of up to $90 \%$ in the Marennes-Oléron Bay in 1988. Along the coasts of France, mortality events among adults generally occur during spring, while those among juveniles are more prevalent during summer (Fleury et al., 2001). Pathogens, predators, sudden environmental changes, spatial and trophic competition, and toxic algal blooms are the most common causes of mass mortality in oysters (Mackin, 1961). In most cases, however, summer mortality cannot be explained by a single factor. A combination of environmental (biotic and abiotic) and internal (i.e., genetic, physiological and immunological) parameters would be more plausible. 'MOREST', a national multi-disciplinary program co-ordinated by IFREMER, was initiated to investigate the causes of summer mortality in juvenile Pacific oyster C. gigas in France and to propose possible solutions. As part of this program, a multisite field experiment was designed to assess the genetic basis of resistance to summer mortality and the potential value of selection for improving survival of juveniles, known as 'spat,' during their first summer.

Bivalves are well suited to a selective breeding approach because of their high fecundity, the ease of controlling their biological cycles (particularly in oysters), adequate genetic variability, and economic importance (Gosling, 2003). Mahon (1983) listed the main goals for genetic improvement of commercial oyster stains by selective breeding: (i) characters linked to spawning and larval development, (ii) survival and growth from settlement to harvest, (iii) resistance to sub-optimal environmental conditions, and (iv) shell shape. More recently, Sheridan (1997) reported that the vast majority of oyster selection studies focus on growth rate and/or live weight, together with selection for resistance to diseases, shell shape and shell prismatic layer coloration. In bivalves, quantitative genetic studies have investigated a wide range of traits. The most frequently studied trait is growth, which represents almost $93 \%$ of genetic parameter estimations in marine mollusks (Dégremont, 2003). A large number of studies found significant heritability for juvenile and adult growth among a variety of clam, mussel, oyster and scallop species (Lannan, 1972; Haley et al., 1975; Wada, 1984, 1986, 1994; Mallet et al., 1986; Strömgren and Nielsen, 1989; Rawson and Hilbish, 1990, 1991; Toro and Newkirk, 1990, 1991; Crenshaw et al., 1991; Hadley et al., 1991; Hilbish et al., 1993; Jarayabhand and Thavornyutikarn, 1995; Toro et al., 1995; Crenshaw et al., 1996; Toro and Parades, 1996; Ibarra et al., 1999; Brichette et al., 2001; Ernande et al., 2003; Zheng et al., 2004). Even though survival is usually considered a trait difficult to improve through genetic selection (Gjedrem, 1985), a number of papers have reported a significant genetic basis for survival in C. gigas (Beattie et al., 1980; Hershberger et al., 1984, Soletchnik et al., 2002; Ernande et al., 2004). Successful selection to improve resistance to MSX and to Dermo has been achieved in eastern oysters, $C$. virginica (Haskin and Ford 1987; Ragone-Calvo et al., 2003), as well as resistance to bonamiosis in European 
flat oysters, Ostrea edulis (Naciri-Graven et al., 1998) and resistance to Marteilia sydneyi in Sydney rock oyster, Saccostrea glomerata (Nell and Hand, 2003).

Langdon et al. (2003) demonstrated a positive response to selection for yield with realized heritability ranging from 0.01 to 0.50 , indicating that yield can be improved by genetic selection. Because yield is the result of survival and growth, it is important to determine if this genetically determined variation in yield is primarily driven by differences in growth, survival or both traits. This is likely to vary according to site (Dégremont et al., 2005a). In the present paper, we report heritability estimates for survival and growth during the summer period, and genetic correlations between these two traits. These genetic parameters were computed using the data from the experiment described by Dégremont et al. (2005a), who suggested that there is a significant genetic component for spat survival. 


\section{Materials and Methods}

\subsection{Broodstock conditioning and spawning.}

Wild oysters were collected from the Marennes-Oléron Bay in November 2000 and brought to the IFREMER hatchery at La Tremblade, France. These oysters were divided into three random groups of 100 individuals to be used as broodstock for three successive sets of crosses. The sets of oysters were successively placed in conditioning tanks in December, January, and February to promote gametogenesis. After a period of 8 weeks, once oysters were ripe, the sex of ripe broodstock animals was determined and 6 males and 24 females were chosen at random to produce 24 families for each set following a nested half-sib mating design, (each male was mated with four different females). To control fertilization, sperm of each male and eggs of each female were individually collected by stripping the gonads. Gametes were rinsed using a screen and the numbers of eggs and spermatozoids determined for each male and female using an image analyzer (Samba IPS). Each cross was conducted using 3 million eggs mixed with 200 spermatozoids per egg in a beaker containing $200 \mathrm{ml}$ seawater. This high gamete density was created to improve fertilization rates. The mixture was left to rest for 15 minutes. In order to maintain seawater quality, $600 \mathrm{ml}$ seawater was then added to each beaker and the gametes were gently mixed at regular intervals over the next 45 minutes. One hour after fertilization, the zygotes were transferred to the larval room. Crosses following this design were conducted on February 5th, March 5th, and April 18th 2001 resulting in 18 half-sib and 72 full-sib families.

\subsection{Larval and spat culture.}

Each family was reared as described in Ernande et al., (2003). Briefly, larvae were reared in 30-litre conical bottomed tanks with permanent aeration at a regulated temperature of $23^{\circ} \mathrm{C}$. Larvae were fed a mixed diet of cultured micro-algae (Isochrysis galbana, Chaetoceros pumilum, Pavlova lutheri, and Tetraselmis suecica) on a daily basis. Filtered seawater was changed 3 times a week. Larval density was adjusted to 10 and 5 larvae per $\mathrm{ml}$ at days 2 and 7 after fertilization respectively. The excess larvae were stored at $-80{ }^{\circ} \mathrm{C}$ for detection of Ostreid Herpesvirus 1 by PCR (see Barbosa-Solomieu et al., 2005). When the largest larvae had reached $280 \mu \mathrm{m}$ shell length, a set of 2 sieves (100 and 220 $\mathrm{mm}$ ) were then used to collect larvae when the water was changed. The eyed and pediveliger larvae were retained on the $220 \mu \mathrm{m}$ screen and then counted and transferred to a settlement room. Smaller individuals, that passed through the $220 \mu \mathrm{m}$ screen but were retained on $100 \mu \mathrm{m}$, were counted and returned to the larval rearing tanks. This process was repeated on alternate days until all larvae had been moved to the settlement room. Pediveliger larvae were settled on microcultch in 120-litre raceways and reared under standard hatchery conditions with continuous water flow, controlled food ration and temperature (Robert and Gérard, 1999). When spat reached 2 $\mathrm{mm}$, they were transported to the IFREMER nursery in Bouin, France. This occurred 44, 44, and 42 days after fertilization for sets 1,2 , and 3, respectively. The nursery period lasted 2 to 3 months (until oysters could be retained on an $8 \mathrm{~mm}$ sieve) and no mortality was observed during this period. On the day prior to placement in the field, 200 oysters from each family were individually weighed. Each family was divided among 27 bags ( $7 \mathrm{~mm}$ mesh size, 100 $\mathrm{cm} \times 27 \mathrm{~cm}$ ) of 150 oysters. The total weight of oysters in each bag was recorded prior to planting in the field. Due to the differential survival at the larval and settlement stages (Boudry et al., 2002; Ernande et al., 2003) and to limited facilities in the nursery, only halfsib families represented by at least 2 full-sib families were kept for this study. Finally, 17 
half-sib families representing 43 full-sib families were deployed in the field divided into 13, 15 and 15 full-sib families for sets 1, 2 and 3, respectively.

\subsection{Grow-out and sampling protocol}

Growth and survival of oysters were monitored at three sites along French coasts (Fig. 1): Ronce in the Marennes-Oléron bay ( $\left.1^{\circ} 10^{\prime} \mathrm{W}, 45^{\circ} 48^{\prime} \mathrm{N}\right)$, Rivière d'Auray in southern Brittany ( $\left.2^{\circ} 57^{\prime} \mathrm{W}, 47^{\circ} 36^{\prime} \mathrm{N}\right)$ and Baie des Veys in Normandy (1 $\left.{ }^{\circ} 06^{\prime} \mathrm{W}, 4^{\circ} 23^{\prime} \mathrm{N}\right)$. Oysters were raised according to local practices, off-bottom in oyster bags attached to re-bar racks with heavy-duty rubber bands. Oysters were deployed at all three sites on June 20th, July 5th, and August 7th for sets 1, 2, and 3 respectively (i.e., 135, 122 and 108 days after fertilization). Each family was represented by 9 bags at each site that were randomly arranged on the re-bar racks. Survival and individual weight were recorded for all sets in October 2001. Oysters from sets 1, 2, and 3 were therefore grown in the field for 104, 89, and 56 days respectively. Survival was determined by counting live and dead oysters and the total weight of live oysters was recorded for each bag. Individual weights of between 30 and 90 oysters were also recorded for each family at each site. Survival was also evaluated on two intermediate dates: i.e., after 15 and 29 days, after 14 and 33 days, and after 14 and 28 days in the field for sets 1 , 2 and 3 respectively. The importance of field placement timing (i.e. differences between sets) on the studied traits in this experiment was previously discussed by Dégremont et al. (2005a).

\subsection{Data analysis}

Survival analysis: Survival data were treated as Bernouilly data using the SAS GLIMMIX macro (SAS Institute Inc., 1989; Wolfinger and O'Connell, 1993) for generalized linear mixed models, using a probit link whereby survival is considered as a threshold trait underlain by a continuous internal trait on the probit scale (Falconer and MacKay, 1996). More specifically, survival recorded at three points in time (see above) was analyzed by nested-factorial probit analysis with time in the field d (in days) as a continuous covariate. The following models were used for the analysis among sites:

$$
\begin{aligned}
\operatorname{Probit}\left(S_{\mathrm{ijklm}}(\mathrm{d})\right)= & \mathrm{a}_{0}+\mathrm{a}_{1} \cdot \mathrm{d}+\mathrm{a}_{2} \cdot \mathrm{d}^{2}+\alpha_{\mathrm{i}}+\beta_{\mathrm{j}}+\gamma_{\mathrm{k}(\mathrm{j})}+\delta_{\mathrm{l}(\mathrm{k}(\mathrm{j}))}+\mathrm{b}_{1 \mathrm{j} \cdot} \cdot \mathrm{d}+\mathrm{b}_{2 \mathrm{j} \cdot} \cdot \mathrm{d}^{2}+(\alpha \beta)_{\mathrm{ij}}+(\alpha \gamma)_{\mathrm{ik}(\mathrm{j})}+ \\
& (\alpha \delta)_{\mathrm{il}(\mathrm{k}(\mathrm{j}))}+\varepsilon_{\mathrm{ijk} \mathrm{km}}
\end{aligned}
$$

and the analysis within sites:

$\operatorname{Probit}\left(S_{j k l m}(d)\right)=a_{0}+a_{1} \cdot d+a_{2} \cdot d^{2}+\beta_{j}+\gamma_{k(j)}+\delta l(k(j))+b 1 j \cdot d+b 2 j \cdot d^{2}+\varepsilon_{j k l m}$

where $S_{\mathrm{ijklm}}(\mathrm{d})$ is the survival at time $\mathrm{d}$ (in days) of an individual spat $\mathrm{m}$ in the family bred using female $\mathrm{l}$ and male $\mathrm{k}$ nested within set $\mathrm{j}$ and reared in site $\mathrm{i}(0$ if the individual is dead and 1 if alive). All effects except time $d$ were class effects, so that $a_{0}+a_{1} \cdot d+a_{2} \cdot d^{2}$ is the overall polynomial response to time, $\alpha_{\mathrm{i}}$ is the effect of site $\mathrm{i}, \beta_{\mathrm{j}}$ is the effect of set $\mathrm{j}, \gamma_{\mathrm{k}(\mathrm{j})}$ is the effect of male $k$ nested within set $\mathrm{j}, \delta l(\mathrm{k}(\mathrm{j}))$ is the effect of female l nested within male $\mathrm{k}$ and set j, b1j.d+b2j.d $d^{2}$ allows for different responses to time according to sets. $(\alpha \beta)_{\mathrm{ij}},(\alpha \gamma)_{\mathrm{ik}(\mathrm{j})}$ and $(\alpha \delta)_{\mathrm{il}(\mathrm{k}(\mathrm{j}))}$ are the two-way interaction terms between corresponding class effects and $\varepsilon_{\mathrm{ijklm}}$ is the error term. All class effects were classified as random except set effect which was classified as fixed. Interactions were classified as random since they all involved at least one random effect. Preliminary analyses were performed to test more complex models of response to time, i.e., different responses according to sites, males or females, but none was 
significantly different from the one described above (likelihood ratio test; results not shown). The replicate level (i.e. rearing bags) was also found non significant $(P>0.05)$ and was therefore dropped from the model to gain degrees of freedom for subsequent analyses. Interactions between male and set (i.e. field placement timing) could not be tested in our experiment.

Growth analysis: The Shapiro-Wilks test of the SAS UNIVARIATE procedure indicated that $66 \%$ of the 387 individual weight datasets at the replicate level (i.e., rearing bags) were not normally distributed and the Bartlett test of the SAS GLM procedure showed that the data were not homoscedastic. Therefore, individual weight was log-transformed prior to statistical analyses in order to increase the normality of the data and the homogeneity of variance (Neter et al., 1985). Growth was analyzed by performing a random-factor nestedfactorial ANCOVA on the log-individual weight with time d (in days) in the field as continuous variable using SAS GLM (SAS Institute Inc., 1989). The following models were used for the analysis among sites:

$$
\begin{aligned}
\log \left(W_{i j k l m}(d)\right)= & a_{0}+a_{1} \cdot d+\alpha_{i}+\beta_{j}+\gamma_{k(j)}+\delta_{l(k(j))}+b_{1 i} \cdot d+b_{1 j} \cdot d+b_{1 k(j)} \cdot d+b_{1 l(k(j))} \cdot d \\
& +(\alpha \beta)_{i j}+(\alpha \gamma)_{i k(j)}+(\alpha \delta)_{i l(k(j))}+c_{1 i j} \cdot d+c_{1 i k(j)} \cdot d+c_{1 i l(k(j))} \cdot d+\varepsilon_{i j k l m}
\end{aligned}
$$

and within sites:

$\log \left(W_{j k l m}(d)\right)=a_{0}+a_{1} \cdot d+\beta_{j}+\gamma_{k(j)}+\delta_{l(k(j))}+b_{1 j} \cdot d+b_{1 k(j)} \cdot d+b_{1 l(k(j))} \cdot d+\varepsilon_{j k l m}$

The same class effects were used in the model as in the survival analysis (site, set, male, female), but in this case all interactions, i.e., up to three-way interaction terms, were considered since the interactions between time and class effects $\left(b_{1 i}, b_{1 j}, b_{1 k(j)}, b_{11(k(j))}, c_{1 i j}\right.$, $\mathrm{c}_{1 \mathrm{ik}(\mathrm{j})}, \mathrm{c}_{1 \mathrm{il}(\mathrm{k}(\mathrm{j}))}$,) reflected class effects on the slope of log-individual weight regressed against time, i.e. on growth rate. Class effects were treated as fixed or random using the same rule as for survival analysis. Interactions involving at least one random class effect were classified as random. The replicate level (rearing bags) was again found non significant $(P>0.05)$ and was dropped from the analysis. The TEST option of the RANDOM statement was used to define the appropriate F-statistics of the model due to nested effects and interaction effects and because the data were unbalanced, SAS type III sums of squares were used to compute F statistics (Littell et al., 2002). Multiple comparison tests were used to determine differences in means by the Tukey method (LSMEANS).

Genetic parameter estimates: Variance components of survival among sites and within each rearing site were estimated using the corresponding models described above and heritabilities were estimated following the methods described in Lynch and Walch (1998). The additive genetic variance ( $\mathrm{Va}$ ) was estimated as four times the covariance among half sibs, i.e. the male variance component. The ratio between the additive genetic variance and the total phenotypic variance Vt gave the narrow sense heritability $\left(h^{2} n=V a / V t\right)$. Broad sense heritability was calculated as the ratio between four times the female variance component, i.e. total genetic variance $\mathrm{Vg}$, and the total phenotypic variance $\left(\mathrm{h}^{2} \mathrm{~b}=\mathrm{Vg} / \mathrm{Vt}\right)$. Because the female variance component in a nested design includes variation associated with dominance and maternal effects, as well as additive genetic effects, it is therefore important for providing information on the relative significance of these variance components (Ashman, 1999). Finally, heritability was also estimated using both the male ( $\operatorname{Var}(\mathrm{m})$ ) and female $(\operatorname{Var}(\mathrm{f}))$ components as: $\left.\mathrm{h}_{\mathrm{s}+\mathrm{d}}^{2}=2 \mathrm{x}(\operatorname{Var}(\mathrm{m})+\operatorname{Var}(\mathrm{f})) / \mathrm{Vt}\right)$ (Falconer and Mackay, 1996). 
Growth variance components were estimated according to the method described in Ernande et al., (2004) which uses resampling combined with bootstrapping. Briefly, 30 pairs of initial and final weight per full-sib family per site were randomly created in order to obtain a pseudo-individual growth dataset. Then the daily specific growth rate was calculated for an individual as SGR $=\left(\ln \left(\mathrm{W}_{\mathrm{f}}\right)-\ln \left(\mathrm{W}_{\mathrm{i}}\right)\right) / \mathrm{t}$, where $\mathrm{W}_{\mathrm{f}}=$ final individual weight, $\mathrm{W}_{\mathrm{i}}=$ initial individual weight and $t=$ the duration of the presence in the field in days. From this dataset, one value of narrow- and broad-sense heritability was then obtained by performing a nestedfactorial ANOVA among sites and a nested ANOVA for each site with class effects as described before. This operation was repeated 1000 times and the mean of the values gave the definitive heritability estimate. Standard errors were then obtained by bootstrapping data between males and females nested within males and computing the genetic parameter 1000 times according to the previously described resampling procedure. Although this method inflates the error variance, it should leave estimates of the other variance components unbiased.

Additive genetic correlations between traits (i.e., survival and growth) within and among sites (i.e., Ronce, Rivière d'Auray or Baie des Veys) and between sites for the same trait were estimated as $\rho_{\mathrm{a}}=\operatorname{Cov}\left(\mathrm{m}_{1}, \mathrm{~m}_{2}\right) /\left(\operatorname{Var}\left(\mathrm{m}_{1}\right) \times \operatorname{Var}\left(\mathrm{m}_{2}\right)\right)^{1 / 2}$ where $\operatorname{Var}\left(\mathrm{m}_{1}\right), \operatorname{Var}\left(\mathrm{m}_{2}\right)$, and $\operatorname{Cov}\left(\mathrm{m}_{1}, \mathrm{~m}_{2}\right)$ denote the estimates of the male components of variance and covariance (Lynch and Walsh, 1998). Whereas variance components $\operatorname{Var}\left(\mathrm{m}_{1}\right), \operatorname{Var}\left(\mathrm{m}_{2}\right)$ were obtained from the previous analyses at the individual level, male covariances were calculated by using data at the replicate level (i.e. rearing bag). Survival probability was computed for each bag and probit transformed before further analysis. The daily specific growth SGR was calculated for each bag as described earlier, but using the mean individual weights (calculated as the total weight of the live oysters divided by the number of live oysters in the bag considered both at the planting and in October) instead of individual weights. Fixed effects known from previous analyses to influence the two traits (polynomial of time and set for survival, and set for SGR) were removed by performing preliminary analyses with models containing only these effects and recording the residuals. Components of covariance, their standard errors, and their significance level (Wald z test) were then estimated through a covariance analysis on these residuals using SAS Proc MIXED as described in Singer (1998) and Thiébaut et al., (2002). Standard errors for genetic correlations were computed using the delta method for compound random variables described in Lynch and Walsh (1998) since genetic correlation estimates came from two different procedures for variance and covariance components. 


\section{Results}

\subsection{Survival}

Mean survival across sites was 84\% (94, 84 and 75\% in Baie des Veys, Ronce and Rivière d'Auray respectively) (Table 1). All tested factors significantly affected survival except site and the interactions site $\mathrm{x}$ set and site $\mathrm{x}$ female (Table 2). Half-sib families showed mortality ranging from 2 to 34\% in Baie des Veys, from 3 to $69 \%$ in Ronce and from 8 to $82 \%$ in Rivière d'Auray (Figure 2). A significant site by male interaction was found (Table 2) but the half-sib family resulting from male 14 showed the highest mortality in all sites (Figure 2). In the same way, the half-sib families bred from males 4, 7 and 8 had high mortality levels in Ronce and Rivière d'Auray (from 38 to 63\%) and in Baie des Veys (from 9 to $12 \%$ ) compared to the other half-sib families. Conversely, the half-sib families from males 2, 9, 10, 11, 15 and 18 showed lower mortalities compared to the other half-sib families: less than 7\% in Ronce, $12 \%$ in Rivière d'Auray and 6\% in Baie des Veys.

\subsection{Growth}

The plant-out sizes of the different families ranged from 1.05 to $2.58 \mathrm{~g}$ (mean $=1.69 \mathrm{~g} \pm$ 0.36). Phenotypic correlations between survival in the field and initial weight were very low and not significant ( $r=-0.10$ in Ronce, $r=0.09$ in Baie des Veys and $r=0.01$ in Rivière d'Auray). Mean daily specific growth rates (SGR) within site and among sites are given in Table 1 and SGR among half-sib families in Figure 3. SGR ranged from 8.5 to $12.410^{-3}$ $\log (\mathrm{g}) \cdot \mathrm{d}^{-1}$ in Ronce, from 6.7 to $9.610^{-3} \log (\mathrm{g}) \cdot \mathrm{d}^{-1}$ in Rivière d'Auray and from 9.2 to $15.110^{-}$ ${ }^{3} \log (\mathrm{g}) \cdot \mathrm{d}^{-1}$ in Baie des Veys. Significant differences in growth were found across males $(P=$ $0.0002)$ and among sites $(P=0.0001)$ (Table 2$)$ with the best growth in Baie des Veys $(11.7$ $\left.10^{-3} \log (\mathrm{g}) \cdot \mathrm{d}^{-1}\right)$, intermediate growth in Ronce $\left(10.210^{-3} \log (\mathrm{g}) \cdot \mathrm{d}^{-1}\right)$ and the lowest in Rivière d'Auray $\left(8.310^{-3} \log (\mathrm{g}) \cdot \mathrm{d}^{-1}\right)$. No significant site by male interaction was found $(P=0.45)$. In all sites, the half-sib family from male 4 showed the lowest SGR whereas the half-sib family from male 18 showed the highest SGR. A similar finding was observed for the site by female interaction (Table 2). Set effect was significant $(P=0.0125)$ with the highest growth for the oysters in set $3\left(11.110^{-3} \log (\mathrm{g}) \cdot \mathrm{d}^{-1}\right)$, intermediate growth in set $2\left(9.810^{-3} \log (\mathrm{g}) \cdot \mathrm{d}^{-1}\right)$ and lowest growth in set $1\left(9.210^{-3} \log (\mathrm{g}) \cdot \mathrm{d}^{-1}\right)$.

\subsection{Genetic parameters}

The heritability estimates for survival and growth in the three sites are shown in Tables 3 and 4. Narrow- and broad-sense heritability estimates for survival were significantly different from 0 . Narrow-sense heritability values were high among sites $(0.83 \pm 0.40)$, in Ronce (1.08 $\pm 0.46)$ and Rivière d'Auray $(0.89 \pm 0.40)$ and moderate in Baie des Veys $(0.47 \pm 0.20)$ (Table 2). Conversely, broad-sense heritability estimates were lower ranging from $0.07 \pm$ 0.04 in Baie des Veys to $0.38 \pm 0.12$ in Rivière d'Auray (Table 3). The combined estimate of heritability using male and female components was moderate in Baie des Veys $(0.27 \pm 0.10)$ and high in Ronce, Rivière d'Auray and among sites with values ranging from 0.56 to 0.68.

Heritability estimates for growth were lower than those for survival, with none significantly different from 0 within sites. Heritability of growth was significant among sites but with a value of $0.10 \pm 0.05$ (Table 4). Within sites, the heritability estimate for growth was highest in Ronce $(0.15 \pm 0.08)$, intermediate in Baie des Veys $(0.10 \pm 0.06)$ and lowest in Rivière d'Auray $(0.07 \pm 0.07)$ (Table 4). Broad sense heritability estimates were similar to the narrow-sense ones in Ronce and Baie des Veys, but higher in Riviere d'Auray (0.13 \pm 
$0.07)$ and lower for the analyses including all sites (0.06 \pm 0.03$)$. Once again, only the broad sense heritability among sites was significant $(P<0.001)$.

Genetic correlations between survival and growth were low and positive in Ronce ( $\rho \mathrm{a}=$ 0.24 ) and Baie des Veys ( $\rho a=0.17$ ), negative in Rivière d'Auray ( $\rho \mathrm{a}=-0.01$ ) and among sites ( $\rho \mathrm{a}=-0.17$ ), and the only significant correlation was in Ronce (Table 5). Genetic correlations for survival between sites were all positive, very high (0.92 to 1.26) and significantly different from 0 . The opposite was found with genetic correlations for growth which ranged from 0.02 to 0.05 (Table 4). 


\section{Discussion}

The ideal approach for estimating genetic parameters of particular traits is to produce and raise a large numbers of oyster families under common conditions, but this is not straightforward. A mixed-family approach combined with parentage analysis using highly polymorphic microsatellite makers is attractive for studying quantitative genetics (Taris et al., 2005), but its relevance for estimating genetic parameters of family traits, such as survival, remains to be demonstrated. In our study, we produced three successive sets of families in order to increase the number of half- and full-sib families and thus obtain better estimates of genetic parameters. Set effect is therefore a combination of the effects of age, field placement timing, and the duration over which oysters were tested. Our major objective in this study was to investigate the genetic parameters of survival in juvenile $C$. gigas during summer so as to assess whether a selective breeding program could significantly improve resistance to summer mortality. The causes of the summer mortality phenomenon are complex and depend notably on environmental factors that are impossible to control in field experiments. As heavy mortality was observed in some of our families in each set, we concluded that environmental conditions were conducive to summer mortality for each of our three successive sets (Dégremont et al., 2005a).

\subsection{Survival}

Summer mortality is a major concern for $C$. gigas production around the world. Several authors have suggested that a significant genetic component exists for resistance to summer mortality and that selection could improve this trait (Beattie et al.,, 1980; Hershberger et al.,, 1984, Dégremont et al., 2005a) but heritability estimates for summer mortality had not been determined up to now. In our study, juvenile C. gigas mortality ranged from 2 to $82 \%$ during summer, similar to levels observed by Beattie et al., (1980) and Perdue et al., (1981). A high narrow-sense heritability estimate was found in Baie des Veys (0.47) and even higher ones in Ronce and Rivière d'Auray (0.89-1.08) indicating that most phenotypic variance observed was due to additive genetic effects. Lower broad-sense heritability estimates indicate an apparent lack of non-additive (i.e., dominance, maternal and epistatic) variation for survival in juvenile oysters. Only a few studies provide estimates of heritability for survival in marine mollusks to compare with our present results. Low estimated heritabilities for survival were found in Mytilus edulis (0-0.15) (Mallet et al.,, 1986) and Haliolis rufescens (0.11) (Jónasson et al.,, 1999). Ernande et al. (2003) reported heritability estimates that were not significantly different from 0 in 6-month-old C. gigas kept in an intensive nursery system. Our results seem closer to those obtained by Ernande et al. (2004) for 18-month-old oysters tested in either controlled or field conditions $(0.16-0.43)$, as well as those recently presented by Evans and Langdon (in press) concerning survival of oysters over a longer rearing period (0.36 - 0.71). The high heritability estimate obtained in our study also suggests that resistance to summer mortality might be controlled by a limited number of genes (Huvet et al., 2004).

Fitness-related traits, such as fecundity and survival, usually show lower heritabilities than physiological and behavioral traits, which are in turn less heritable than morphological traits (Mousseau and Roff, 1986). Several hypotheses can be proposed to explain how genetic variation for survival is maintained in French $C$. gigas populations. Among these, genotype by environment interaction can be excluded in the present case because it was weak and because genetic correlations for survival across environments were all significant and close to 1 (0.92 - 1.26, Table 5).

The first hypothesis we propose is related to the lack of effective stabilizing selection in French C. gigas populations since the introduction of the species in the early 1970s. Oyster 
farming occurs in the natural environment where very few environmental parameters (i.e., density, protection from predators) are controlled. In consequence, a period of 30 years might be too short for stabilizing selection to become established. Furthermore, environmental conditions are highly spatially and temporally variable, so selection pressures are likely to vary in time and space. Another hypothesis is that the introduction of $C$. gigas to the French coastline is sufficiently recent that it could still be experiencing directional selection, leading to maintenance or even increasing genetic variance. An increase in frequency of rare genotypes occurs as a trait responds to directional selection and may dramatically increase the genetic variance (Barton and Turelli, 1987) by as much as six times for some traits (Reeve, 2000).

The second possibility that could explain the high additive variance for survival is related to farming practices with $C$. gigas in France. For the last two decades, two spat collection areas, Marennes-Oléron and Arcachon, have provided 90\% of all cultivated oysters with only $10 \%$ from hatcheries (Robert and Gérard, 1999). Wild spat usually experience about $80 \%$ of mortality during the first year, essentially due to predation and overcrowding, before they are distributed at growing sites along the French coast. Furthermore, during the farming period, oysters are transferred among different growing areas (Goulletquer and Le Moine, 2002). For example, large quantities of oysters, originating from either MarennesOléron or Arcachon, are grown in Brittany and Normandy, and then transferred to the Marennes-Oléron "claires" (oyster ponds) before being marketed. This could produce migration-niche selection, a type of disruptive selection combined with a migration-selection balance, where alleles are introduced from outside populations at a rate faster than they can be eliminated by selection. Thus, oysters, that experienced different selective pressures due to the fluctuating environmental conditions could mate and maintain high genetic variance over generations. Additionally, mortality differs according to culture techniques, with higher mortality in on-bottom than in off-bottom culture (Soletchnik et al.,, 1999). Furthermore, feral oysters (i.e., wild populations) represent a large biomass, estimated to be $23 \%$ of the cultivated oyster biomass in Marennes-Oléron Bay (Goulletquer and Le Moine, 2002). Wild populations experience various selective pressures, such as those due to predators, competition for space, silt and other environmental effects. For example, sub-tidal oysters usually grow faster, show little summer mortality and allocate more energy to reproduction than those living in the inter-tidal zone (as do most cultivated oysters) (Ernande, 2001). Consequently, selective pressures are likely to be different between sub-tidal and inter-tidal zones. All these factors, combined with temporal variability, could easily lead to the maintenance of the high genetic variance, as revealed in our study.

The third hypothesis that could explain high genetic variance involves trade-offs between survival and other fitness-related traits. Our results, together with those published by Ernande et al. (2004) do not show any significant trade-off between survival and growth. However, Ernande et al. (2004) found a clear genetic trade-off between survival and reproductive allocation in $C$. gigas adults that was influenced by food abundance, this parameter being related to spatial and temporal variation in the environment. Interestingly, the genetic correlations between reproductive effort and both survival and growth were negative when food availability was low but positive when it was high. These sign reversals may reflect genetic variability in resource acquisition, which is only expressed when food is abundant and might contribute to the maintenance of genetic variation for resistance to summer mortality.

Finally, life-history trait modifications under hatchery propagation may provide an explication for the maintenance of genetic variation in survival. In our study, oysters were produced during late winter and early spring and then grown under intensive nursery conditions before being deployed in the field at 4-5 months old. Consequently, these oysters 
may have begun their active reproductive phase (i.e., gametogenesis) in the nursery and encountered suitable environmental conditions when put in the field during their first summer. In French wild populations in contrast, reproduction occurs in July and August. Oyster larvae that settle during summer therefore only reproduce for the first time during the following summer, once they are one year old. Thus, the reproductive process in oysters less than one year old could have revealed genetic variation for survival produced in our experiment, while no selection (or only weak selection) occurs early in life in wild spat. Dégremont et al., (2005a) suggested that a larger proportion of oysters became mature in Ronce and Rivière d'Auray due to the higher seawater temperature compared to Baie des Veys. Since oysters are not all then sexually mature, especially in Baie des Veys, genetic variance in survival was not fully expressed in the experimental population. In wild populations, genetic variance for this trait is not revealed at all, which would maintain this variation in the wild. This hypothesis also requires that genetic variance for survival is also unexpressed later in life; such there is no selection at all on this trait. First results on effects of age and environment on the summer mortality in C. gigas showed evidence that survival to 0.5 years old is a different trait (depending on different genes) than survival to 1.5 years old, especially in Rivière d’Auray (Dégremont et al., 2005b). Phenotypic and genetic correlations between survival performance during the first and second summers will be examined in a future paper. To conclude, we consider that the maintenance of high genetic variance in the sampled wild population might result from a combination of the different points described above.

The very high genetic correlation between survival across the three sites indicates that the genotype by environment interaction is particularly low (Table 5). Consequently, a single selective breeding program to improve survival of juvenile $C$. gigas $(<1$ year) should be effective for all growing areas along the French coast. In contrast, genetic correlations between growth and survival were low in all sites (only one was significantly different from 0 ) but positive in Ronce and Baie des Veys. This supports the results found by Ernande et al. (2003) and indicates that a selective breeding program to improve survival would also result in a small increase in growth. Harvestable yield could therefore be significantly improved by choosing survival as a primary character for selective breeding, because yield is the combined result of both survival and growth and depends mainly on variation in mortality (Dégremont et al., 2005a).

\subsection{Growth}

Genetic variation for growth or traits related to growth at a specific age has been widely studied in marine mollusks, especially in oysters (Dégremont, 2003). However, very few studies have obtained heritability estimates for spat growth. The narrow-sense heritability estimates for growth were low in all sites of our study, ranging from $0.07 \pm 0.07$ to $0.15 \pm$ 0.08 in 6 to 8-month-old C. gigas (Table 4). Ernande et al. (2003) found similar values (0.05 \pm 0.18 ) for 6 -month-old oysters when they were kept in intensive nursery conditions. The lower standard deviation seen in our study is likely to be due to the higher number of families used. It is clear that additive genetic variation for growth in juvenile $C$. gigas is lower than for survival. In O. edulis, Toro and Newkirk (1990) reported a similar value at 6 months old $(0.14 \pm 0.12)$ while heritability was higher at 18 months old $(0.24 \pm 0.20)$. However, two other studies reported higher heritability during the spat life stage in oysters. Davis (2000) obtained narrow-sense heritabilities ranging from $0.10 \pm 0.05$ to $0.51 \pm 0.15$ for live weight at seven months in $C$. virginica depending on the founder population. Higher estimates were obtained in flat oyster $O$. chilensis at eight months with a realized heritability ranging from $0.35 \pm 0.08$ to $0.69 \pm 0.11$ (Toro et al., 1995). 
Our results confirm that growth rate in bivalve mollusks usually exhibits low levels of heritable variation (Rawson and Hilbish, 1990). The low heritability at all sites suggests that genes influencing growth have been selected for and that genetic variation for that trait may have been reduced as a result. Indeed, our parental population was collected from an area were oysters are harvested according to their weight. Fast growing oysters are therefore harvested after a shorter period ( $2-3$ years) than slow growing ones ( 4 years or more), so exploitation is strongly size-selective. Since farmed oysters represent the large majority of the total oyster biomass, the recruitment is mostly offspring of farmed stocks, such that selective exploitation can readily affect subsequent generations. This might result in a selection for reduced growth, and a subsequent decrease in genetic variance of this trait. This hypothesis is supported by the data on farmed oysters, showing that a significant decrease in growth rate and delay in spawning timing have developed since the introduction of $C$. gigas to France. However, the relative importance of (1) phenotypic plasticity in response to environmental changes and (2) exploitation-induced evolution remain to be determined. Finally, low genetic correlations between growth and survival within site and for growth across environments suggest that different genes contribute to these traits (Table 5).

\section{Conclusion}

Our study showed a high genetic basis for survival in oysters less than a year old. Several hypotheses might explain how high additive genetic variance is maintained in C. gigas in Marennes-Oléron Bay: lack of stabilizing selection, directional selection, cultural practices, trade-offs, and life-history trait modifications related to hatchery propagation. High additive genetic correlation for survival across environments, associated with low genetic correlation between survival and growth suggest that a selective breeding program based at a single site should significantly improve the resistance of juvenile oysters to the summer mortality phenomenon along French Atlantic coasts. As a result, the harvestable yield could also be significantly improved, benefiting oyster production in France. Further studies are needed to assess genotype by environment interaction at a larger geographic scale and follow survival up to market size (as in Evans and Langdon, in press). The establishment of a full-scale family-based selective breeding program is currently being discussed with the French oyster production industry.

\section{Acknowledgements}

The authors wish to thank the hatchery team (Laboratoire de Génétique et Pathologie, Ifremer, La Tremblade, France) and the nursery team (Laboratoire Conchylicole des Pays de Loire, Ifremer, Bouin, France) for their technical assistance during the larval and nursing rearing periods. The authors are particularly grateful to P. Phélipot, S. Heurtebise and M. Nourry. This work could not have been completed without the help of many other people with the preparation of the bags prior to field placement and with the counting on sampling dates. We also thank A. Langlade, J.-L. Seugnet, F. Cornette, C. Simonne, M. Ropert and P. Soletchnik for their assistance with the maintenance of oysters in the field, S.K. Allen, Jr. for editorial suggestions on this manuscript and $\mathrm{H}$. McCombie for her advice on the English. 


\section{References}

Ashman, T.L., 1999. Quantitative genetics of floral traits in a gynodioecious wild strawberry Fragaria virginiana: implications of the independent evolution of female and hermaphrodite floral phenotypes. Heredity 83, 733-741.

Barbosa-Solomieu, V., Dégremont, L., Vazquez-Juarez, R., Ascencio-Valle, F., Boudry, P., Renault, T., 2005. Transmission of OsHV-1 among hatchery-reared larvae of Pacific oyster (Crassostrea gigas): evidence for vertical transmission. Virus Res. 107, 47-56.

Barton, N.H., Turelli, M., 1987. Adaptive landscapes, genetic distance and the evolution of quantitative characters. Genet. Res. 49, 157-173.

Beattie, J., Chew, K., Hershberger, W., 1980. Differential survival of selected strains of Pacific Oysters (Crassostrea gigas) during summer mortality. Proc. Nat. Shellfish. Ass. 70, 184-189.

Bodoy, A., Garnier, J., Razet, D., Geairon, P., 1990. Mass mortalities of oysters (Crassostrea gigas) during spring 1988 in the bay of Marennes-Oléron, related to environmental conditions. Note ICES CM 1990 / K : 11, 1-23.

Boudry, P., Collet, B., Cornette, F., Hervouet, V., Bonhomme, F., 2002. High variance in reproductive success of the Pacific oyster (Crassostrea gigas, Thunberg) revealed by microsatellite-based parentage analysis of multifactorial crosses. Aquaculture 204, 283-296.

Brichette, I., Reyero, M.I., García, C., 2001. A genetic analysis of intraspecific competition for growth in mussel cultures. Aquaculture 192, 155-169.

Comps, M., 1983. Recherches histologiques et cytologiques sur les infections intracellulaires des mollusques bivalves marins. PhD thesis, Montpellier, France.

Comps, M., Bonami, J. R., Vago, C., Razet, D., 1976. La mise en évidence d'une infection virale chez l'huître portugaise à l'occasion de l'épizootie de 1970-1974. Science et Pêche, Bull. Inst. Pêches marit. 256, 13-15.

Crenshaw, J.W., Hefferman, P.B., Walker, R.L., 1991. Heritability of growth rate in the southern bay scallop, Argopecten iradians concentrius (Say, 1822). J. Shellfish Res. 10, 55-63.

Crenshaw, J.W., Heffernan, P.B., Walker, R.L., 1996. Effect of growout density on heritability of growth rate in the northern quahog, Mercenaria mercenaria (Linnaeus, 1758). J. Shellfish Res. 15, 341-344.

Davis, C.V., 2000. Estimation of narrow-sense heritability for larval and juvenile growth traits in selected and unselected sub-lines of eastern oysters, Crassostrea virginica. J. Shellfish Res. 19, 613.

Dégremont, L., 2003. Genetic basis of summer mortality and relationship with growth in juvenile Pacific cupped oysters Crassostrea gigas. PhD thesis, Université de Caen, France.

Dégremont, L., Bédier, E., Soletchnik, P., Ropert, M., Huvet, A., Moal, J., Samain, J-F., Boudry, P., 2005a. Relative importance of family, site, and field placement timing on survival, growth and yield of hatchery-produced Pacific oyster spat (Crassostrea gigas). Aquaculture 249, 213-229.

Dégremont, L., Boudry, P., Soletchnik, P., Bédier, E., Ropert, M., Samain, J-F., 2005b. Effects of age and environment on the summer mortality in cupped oyster Crassostrea gigas during the first two years. J. Shellfish Res. 24, 650.

Dickie, L.M., Boudreau, P.R., Freeman, K.R., 1984. Influences of stock and site on growth and mortality in the blue mussel (Mytilus edulis). Can. J. Fish. Aquat. Sci. 41, 134140. 
Ernande, B., 2001. Développement, plasticité phénotypique et évolution. PhD thesis, Université de La Rochelle, France.

Ernande, B., Clobert, J., McCombie, H., Boudry, P., 2003. Genetic polymorphism and tradeoffs in the early life-history strategy of the Pacific oyster, Crassostrea gigas (Thunberg, 1795): a quantitative genetic study. J. Evol. Biol. 16, 399-414.

Ernande, B., Boudry, P., Clobert, J., Haure, J., 2004. Plasticity in resource allocation based life history traits in the Pacific oyster, Crassostrea gigas. I Spatial variation in fund abundance. J. Evol. Biol. 17, 342-356.

Evans, S., Langdon C. Effects of genotypexenvironment interactions on the selection of broadly adapted Pacific oysters (Crassostrea gigas), Aquaculture (2006), doi:10.1016/j.aquaculture.2006.07.022.

Falconer, D.S., MacKay, T.F.C., 1996. An Introduction into Quantitative Genetics, 4th edn. Longman, Harlow, UK

FAO, 2004a. Aquaculture production: Quantities 1950-2001. Fishstat Plus. Published electronically on the internet, available directly from http://www.fao.org/fi/statist/fisoft/FISHPLUS.asp\#Download.

FAO, 2004b. Aquaculture production: Values 1984-2001. Fishstat Plus. Published electronically on the internet, available directly from http://www.fao.org/fi/statist/fisoft/FISHPLUS.asp\#Download.

Fleury, P.G., Goyard, E., Mazurie, J., Claude, S., Bouget, J.F., Langlade, A., Le Coguic, Y., 2001. The assessing of Pacific oyster (Crassostrea gigas) rearing performances by the IFREMER/REMORA network : method and first results (1993-98) in Brittany (France). Hydrobiologia 465, 195-208.

Gilmour, A.R., Gogel, B.J., Cullis, B.R., Welham, S.J., Thompson, R., 2002. ASReml User Guide Release 1.0. VSN International Ltd, Hemel Hempstead, HP11ES, UK.

Gjedrem, T., 1985. Improvement of productivity through breeding schemes. Geojournal 10, 233-241.

Glude, J.B., 1975. A summary report of Pacific coast oyster mortality investigations 19651972. Proceedings of the Third U.S.-Japan Meeting on Aquaculture, Tokyo, Japan. October 15-16, 1974, pp. 1-28.

Gosling, E., 2003. Genetics in aquaculture. Bivalve Molluscs, Biology, Ecology and Culture, edited by Fishing News Books, Blackwell, Oxford, pp. 333-369.

Goulletquer, P., Le Moine, O., 2002. Shellfish farming and coastal zone management (CZM) developement in the Marennes-Oléron Bay and Charentais Sounds (Charente Maritime, France): a review of recent developments. Aquacult. Int. 10, 507-525.

Grizel, H., Héral, M., 1991. Introduction into France of the Japanese oyster (Crassostrea gigas). J. Cons. Int. Explor. Mer 47, 399-403.

Hadley, M.H., Dillon, R.T., Manzi, J.J., 1991. Realized heritability of growth rate in the hard clam Mercenaria mercenaria. Aquaculture 93, 109-119.

Haley, L.E., Newkirk, G.F., Waugh, D.W., Doyle, R.W., 1975. A report on the quantitative genetics of growth and survivorship of the American oyster, Crassostrea virginica under laboratory conditions. 10th European symposium on Marine Biology, Sept. 1723, Ostend, Belgium, pp. 221-228.

Haskin, H.H., Ford, S.E., 1987. Breeding for disease resistance in mollusks. World Symposium on selection, hybridation and genetic engineering in aquaculture, Bordeaux, France, pp. 431-441.

Héral, M., 1989. L’ostréiculture française traditionnelle. Aquaculture, edited by Lavoisier and coordinated by Barnabé, Paris, pp. 347-397.

Hershberger, W.K., Perdue, J.A., Beattie, J.H., 1984. Genetic selection and systematic breeding in Pacific oyster culture. Aquaculture 39, 237-245. 
Hilbish, T.J., Winn, E.P., Rawson, P.D., 1993. Genetic variation and covariation during larval and juvenile growth in Mercenaria mercenaria. Mar. Biol. 115, 97-104.

Huvet, A., Herpin, A., Dégremont, L., Labreuche, Y., Samain, J.F., Cunningham, C, 2004. The identification of genes from the oyster Crassostrea gigas that are differentially expressed as a result of summer mortality. Gene 343, 211-220.

Hine, P.M., Wesney, B., Hay, B.E., 1992. Herpesviruses associated with mortalities among hatchery-reared larval pacific oysters Crassostrea gigas. Dis. Aquat. Org. 12, 135-142.

Houle, D., 1992. Comparing evolvability and variability of quantitative traits. Genetics 130, 195-204.

Ibarra, A.M., Ramirez, J.L., Ruiz, C.A., Cruz, P., Avila, S., 1999. Realized heritabilities and genetic correlation after dual selection for total weight and shell width in catarina scallop (Argopecten ventricosus). Aquaculture 175, 227-241.

Jarayabhand, P., Thavornyutikarn, M., 1995. Realized heritability estimation on growth rate of oyster, Saccostrea cucullata Born, 1778. Aquaculture 138, 111-118.

Jonasson, J., Stefansson, S.E., Gudnason, A., Steinarsson, A., 1999. Genetic variation for survival and shell length of cultured red abalone (Haliotis rufescens) in Iceland. J. Shellfish Res. 18, 621-625.

Koganezawa, A., 1975. Present status of studies on the mass mortality of cultured oysters in Japan and its prevention. Proceedings of the Third U.S.-Japan Meeting on Aquaculture, October 15-16, 1974, Tokyo, Japan, pp. 29-34.

Langdon, C., Evans, F., Jacobson, D., Blouin, M., 2003. Yields of cultured Pacific oysters Crassostrea gigas Thunberg improved after one generation of selection. Aquaculture, 220, 227-244.

Lannan, J.E., 1972. Estimating heritability and predicting response to selection for the Pacific oyster, Crassostrea gigas. Proc. Natl Shellfish. Ass. 62, 62-66.

Littell, R.C., Stroup, W.W., Freund, R.J., 2002. SAS® for Linear Models. Fourth Edition. SAS Institute Inc., Cary, NC.

Lynch, M., Walsh, B., 1998. Genetics and Analysis of Quantitative Traits. Sinauer Associates, Sunderland, Massachusetts.

Mackin, J.G., 1961. Mortalities of oysters. Proc. Nat. Shellfish Ass. 50, 21-40.

Mahon, G.A.T., 1983. Selection goals in oyster breeding. Aquaculture 33, 141-148.

Mallet, A.L., Freeman, K.R., Dickie, L.M., 1986. The genetics of production characters in the blue mussel Mytilus edulis. I. A preliminary analysis. Aquaculture 57, 133-140.

Maurer, D., Comps, M., 1986. Mortalités estivales de l’huître Crassostrea gigas dans le bassin d'Arcachon : facteurs du milieu, aspects biochimiques et histologiques. Pathology in Marine Aquaculture, Edited by Vivarès, C.P., Bonami, J.R. and E. Jaspers, European Aquaculture Society, Special Publication Nº 9, Bredene, Belgium, pp. 29-41.

Mousseau, T.A., Roff, D.A., 1986. Natural selection and the heritability of fitness components. Heridity 59, 181-197.

Naciri-Graven, Y., Martin, A. G., Baud, J.-P., Renault, T., Gérard, A., 1998. Selecting the flat oyster Ostrea edulis (L.) for survival when infected with the parasite Bonamia ostreae. J. Exp. Mar. Biol. Ecol. 224, 91-107.

Nell, J. A., Hand, R. E., 2003. Evaluation of the progeny of second-generation Sydney rock oyster Saccostrea glomerata (Gould, 1850) breeding lines for resistance to QX disease Marteilia sydneyi. Aquaculture 228, 27-35.

Neter, J., Wasserman, W., Kutner, M.H., 1985. Applied linear statistical models: Regression, analysis of covariance and experimental designs. R.D. Irwin, Illinois. 
Perdue J.A., Beattie, J.H., Chew, K.K., 1981. Some relationships between gametogenic cycle and summer mortality phenomenon in the Pacific oyster (Crassostrea gigas) in Washington State. J. Shellfish Res. 1, 9-16.

Ragone-Calvo, L.M., Calvo, G.W., Burreson, E.M., 2003. Dual disease resistance in a selectively bred eastern oyster, Crassostrea virginica, strain tested in Chesapeake Bay. Aquaculture 220, 69-87.

Rawson, P.D., Hilbish, T.J., 1990. Heritability of juvenile growth for the hard clam Mercenaria mercenaria. Mar. Biol. 105, 429-436.

Rawson, P.D., Hilbish, T.J., 1991. Genotype-environment interaction for juvenile growth in the hard clam Mercenaria mercenaria (L). Evolution 45, 1924-1935.

Reeve, J.P, 2000. Predicting long-term response to selection. Genetical Research 75, 83-94.

Robert, R., Gérard, A., 1999. Bivalve hatchery technology: The current situation for the Pacific oyster Crassostrea gigas and the scallop Pecten maximus in France. Aquat. Living Resour. 12, 121-130.

SAS Institute Inc., 1989. SAS/STAT® User’s Guide. Version 6, Fourth Edition, Volume 2. SAS Institute Inc., Cary, NC.

SAS Institute Inc., 1995. Basis statistics using SAS/STAT®, Software Course Notes. SAS Institute Inc., Cary, NC.

Singer, J.D., 1998. Using SAS PROC MIXED to fit multilevel models, hierarchical models, and individual growth models. J. Educat. Behav. Stat. 24, 323-355.

Shatkin, G., Shumway, S.E., Hawes, R., 1997. Considerations regarding the possible introduction of the Pacific oyster (Crassostrea gigas) to the Gulf of Maine: A review of global experience. J. Shellfish Res. 16, 463-477.

Sheridan, A.K., 1997. Genetic improvement of oyster production--a critique. Aquaculture 153, 165-179.

Soletchnik, P., Huvet, A., Le Moine, O., Razet D., Geairon, P., Faury N., Goulletquer, P., Boudry, P., 2002. A comparative field study of growth, survival and reproduction of Crassostrea gigas, C-angulata and their hybrids. Aquat. Living Resour. 15, 243-250.

Soletchnik, P., Le Moine, O., Faury, N., Razet, D., Geairon, P., Goulletquer, P., 1999. Mortalité de l'huître Crassostrea gigas dans le bassin Marennes-Oléron : étude de la variabilité spatiale de son environnement et de sa biologie par un système d’informations géographiques (SIG). Aquat. Living Resour. 12, 131-143.

Strömgren, T., Nielsen, M.V., 1989. Heritability of growth in larvae and juveniles of Mytilus edulis. Aquaculture 80, 1-6.

Taris, N., Baron, S., Sharbel, T.F., Sauvage, C., Boudry, P., 2005. A combined microsatellite multiplexing and boiling DNA extraction method for high throughput parentage analyses in the Pacific Oyster (Crassostrea gigas). Aquaculture Res. 36, 516-518.

Thiébaut, R., Jacqmin-Gadda, H., Chêne, G., Leport, C., Commenges, D., 2002. Bivariate linear mixed models using SAS proc MIXED. Comp. Meth. Prog. Biomed. 69, 249256.

Toro, J.E., Newkirk, G.F., 1990. Divergent selection for growth rate in the European oyster Ostrea edulis: response to selection and estimation of genetic parameters. Mar. Ecol. Prog. Ser. 62, 219-227.

Toro, J.E., Newkirk, G.F., 1991. Response to artificial selection and realized heritability estimate for shell height in the Chilean oyster Ostrea chilensis. Aquat. Living Resour. 4, 101-108.

Toro, J.E., Parades, L.I., 1996. Heritability estimates of larval shell length in the Chilean blue mussel Mytilus chilensis, under different food densities. Aquat. Living Resour. 9, 347350. 
Toro, M., Sanhueza, M.A., Winter, J.E., Aguila, P., Vergara, M,. 1995. Selection response and heritability estimates for growth in the chilean oyster Ostrea chilensis (Philippi, 1845). J. Shellfish Res. 14, 87-92.

Wada, K.T., 1984. Breeding study of the pearl oyster, Pinctada fucata. Bull. Natl. Res. Inst. Aquacult. Japan 6, 79-157.

Wada, K.T., 1986. Genetic selection for shell traits in the Japanese pearl oyster, Pinctada fucata martensii. Aquaculture 57, 171-176.

Wada, K.T., 1994. Genetics of pearl oysters in relation to aquaculture. Jpn Agric. Res. Q. 28, 276-282.

Wolfinger, R., O'Connell, M., 1993. Generalized Linear Mixed Models: A PseudoLikelihood Approach. J. Stat. Comp. Sim. 48, 233-243

Zheng, H., Zhang, G., Liu, X., Zhang, F., Guo, X., 2004. Different responses to selection in two stocks of the bay scallop, Argopecten irradians irradians Lamarck (1819). J. Exp. Mar. Biol. Ecol. 313, 213-223. 
Figure 1: Field site locations at Ronce, Rivière d’Auray (RA), and Baie des Veys (BDV). 


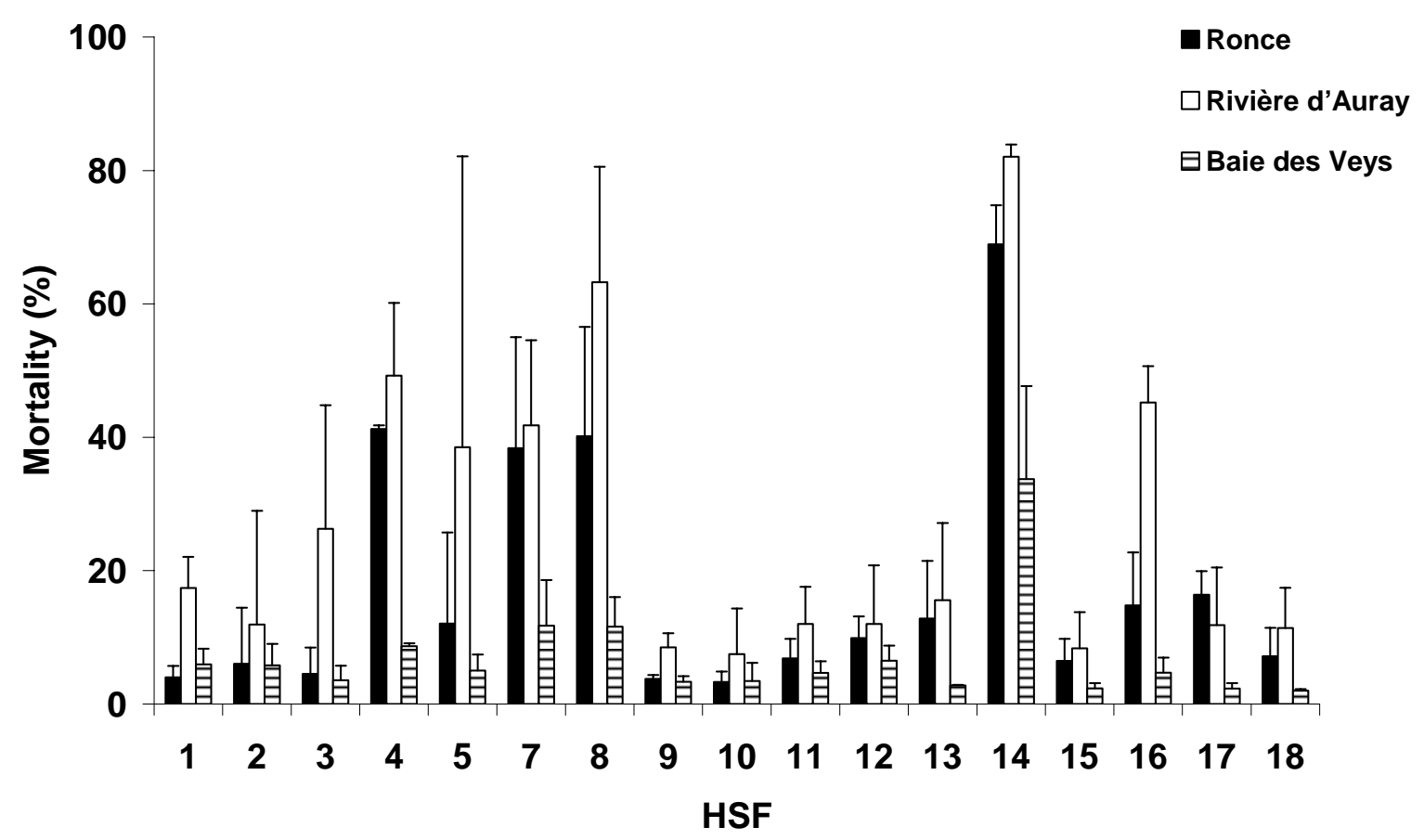

Figure 2: Mortality of half-sib families (HSF) and standard deviation between full-sib families recorded in October 2001 at Ronce, Rivière d'Auray and Baie des Veys. 


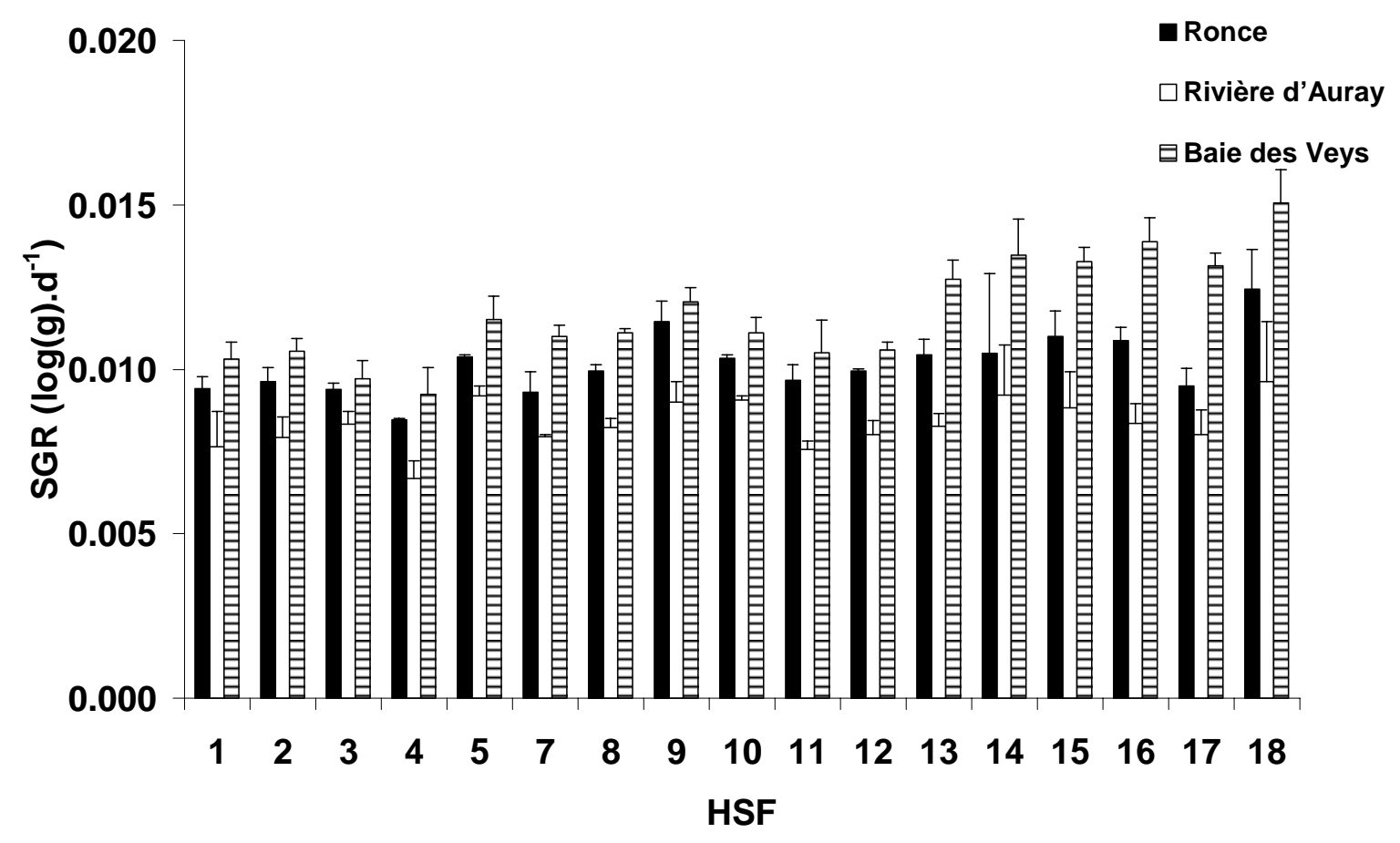

Figure 3: Daily specific growth rate (SGR) of half-sib families (HSF) and standard deviation between full-sib families recorded in October 2001 at Ronce, Rivière d'Auray and Baie des Veys. 

Table 1: Mean (SE) for survival (\%) and daily specific growth (log.(g) $\mathrm{d}^{-1}$ ) within and among sites in October 2001.

\begin{tabular}{ccccc}
\hline Trait & Ronce & Rivière d’Auray & Baie des Veys & All sites \\
\hline Survival & $84.1(18.2)$ & $75.2(23.1)$ & $93.5(7.5)$ & $84.3(15.4)$ \\
Growth & $10.210^{-3}(1.1)$ & $8.310^{-3}(1.0)$ & $11.710^{-3}(1.7)$ & $10.110^{-3}(1.9)$ \\
\hline
\end{tabular}


Table 2: Probit analysis of survival and analysis of covariance of weight among sites.

\begin{tabular}{|c|c|c|c|c|c|c|}
\hline \multirow[b]{2}{*}{ Source } & \multirow[b]{2}{*}{$\mathrm{Df}^{\mathrm{b}}$} & \multicolumn{2}{|c|}{ Survival } & \multicolumn{3}{|c|}{ Growth $^{\text {ac }}$} \\
\hline & & F or Z & $P$ & MS & F & $P$ \\
\hline Site & 2 & 0.91 & 0.1803 & 100.07 & 333.17 & 0.0001 \\
\hline Set & 2 & 34.07 & 0.0002 & 27.18 & 6.09 & 0.0125 \\
\hline Male (set) & 14 & 2.11 & 0.0176 & 4.46 & 4.96 & 0.0002 \\
\hline Female (male (set)) & 26 & 3.07 & 0.0011 & 0.90 & 3.08 & 0.0003 \\
\hline Site $x$ Set & 4 & 1.09 & 0.1381 & 5.80 & 19.31 & 0.0001 \\
\hline Site x Male (set) & 28 & 2.38 & 0.0088 & 0.30 & 1.03 & 0.4526 \\
\hline Site x Female (male (set)) & 52 & 1.62 & 0.0528 & 0.29 & 0.97 & 0.5430 \\
\hline Error & 258/31929 & 145.06 & & 0.30 & & \\
\hline \multicolumn{7}{|c|}{${ }^{a}$ Here, we only present the statistical tests for interactions between $\log ($ weight) regressed } \\
\hline \multicolumn{7}{|c|}{ b Degrees of freedom correspond to both traits except for error df, for which the two values } \\
\hline \multicolumn{7}{|c|}{ are shown as survival df/growth df. } \\
\hline${ }^{\mathrm{C}}$ The denominator for tes & set is mal & t), ma & t) is $\mathrm{fe}$ & (mal & ), sit & site $\mathrm{x}$ \\
\hline
\end{tabular}


Table 3: Variance components and narrow- and broad-sense heritabilities $\left(h^{2} \mathrm{n}\right.$ and $\mathrm{h}^{2} \mathrm{~b}$ respectively) (S.E.) for survival in C. gigas less than one year old within each site and for all sites.

\begin{tabular}{|c|c|c|c|c|}
\hline Variance & Ronce & Rivière d'Auray & Baie des Veys & All sites \\
\hline $\mathrm{Va}$ & 1.728 & 1.619 & 0.596 & 1.414 \\
\hline Vg & 0.518 & 0.697 & 0.093 & 0.594 \\
\hline Venv & & & & 0.201 \\
\hline Venv(a) & & & & 0.180 \\
\hline Venv(g) & & & & 0.077 \\
\hline Verror & 1.081 & 1.116 & 1.168 & 0.840 \\
\hline Vtotal & 1.598 & 1.813 & 1.260 & 1.712 \\
\hline$h^{2} n$ & $1.08 \pm 0.46^{*}$ & $0.89 \pm 0.40 *$ & $0.47 \pm 0.20^{* *}$ & $0.83 \pm 0.40^{*}$ \\
\hline$h^{2} b$ & $0.32 \pm 0.11^{* *}$ & $0.38 \pm 0.13^{* * *}$ & $0.07 \pm 0.04^{*}$ & $0.35 \pm 0.13^{* *}$ \\
\hline$h^{2} s+d$ & $0.68 \pm 0.23$ & $0.62 \pm 0.20$ & $0.27 \pm 0.10$ & $0.56 \pm 0.17$ \\
\hline
\end{tabular}


Table 4: Variance components and narrow- and broad-sense heritabilities $\left(h^{2} n\right.$ and $h^{2} b$ respectively) (S.E.) for growth in C. gigas younger than one year old within each site and for all sites.

\begin{tabular}{|c|c|c|c|c|}
\hline Variance & Ronce & Rivière d'Auray & Baie des Veys & All sites \\
\hline $\mathrm{Va}$ & $1.21610^{-5}$ & $0.62210^{-5}$ & $0.91510^{-5}$ & $0.91410^{-5}$ \\
\hline $\mathrm{Vg}$ & $0.97310^{-5}$ & $1.09610^{-5}$ & $0.89410^{-5}$ & $0.50510^{-5}$ \\
\hline Venv & & & & $0.93010^{-5}$ \\
\hline Venv(a) & & & & $0.09410^{-5}$ \\
\hline Venv(g) & & & & $0.44310^{-5}$ \\
\hline Verror & $7.12910^{-5}$ & $7.27810^{-5}$ & $7.32510^{-5}$ & $7.21510^{-5}$ \\
\hline Vtotal & $8.10210^{-5}$ & $8.37410^{-5}$ & $8.22010^{-5}$ & $10.10110^{-5}$ \\
\hline$h^{2} n$ & $0.15 \pm 0.08$ & $0.07 \pm 0.07$ & $0.11 \pm 0.08$ & $0.10 \pm 0.05^{* * *}$ \\
\hline$h^{2} b$ & $0.12 \pm 0.04$ & $0.13 \pm 0.07$ & $0.11 \pm 0.06$ & $0.06 \pm 0.03^{* * *}$ \\
\hline
\end{tabular}

Va, Vg, Venv, Venv(a), Venv(g) are the additive, genetic, environment, additive by environment interaction and genetic by environment interaction variances.

*: $P<0.05$; **: $P<0.01$; ***: $P<0.001$ 
Table 5: Genetic correlations ( \pm S.E.) for survival and growth in C. gigas less than one year old.

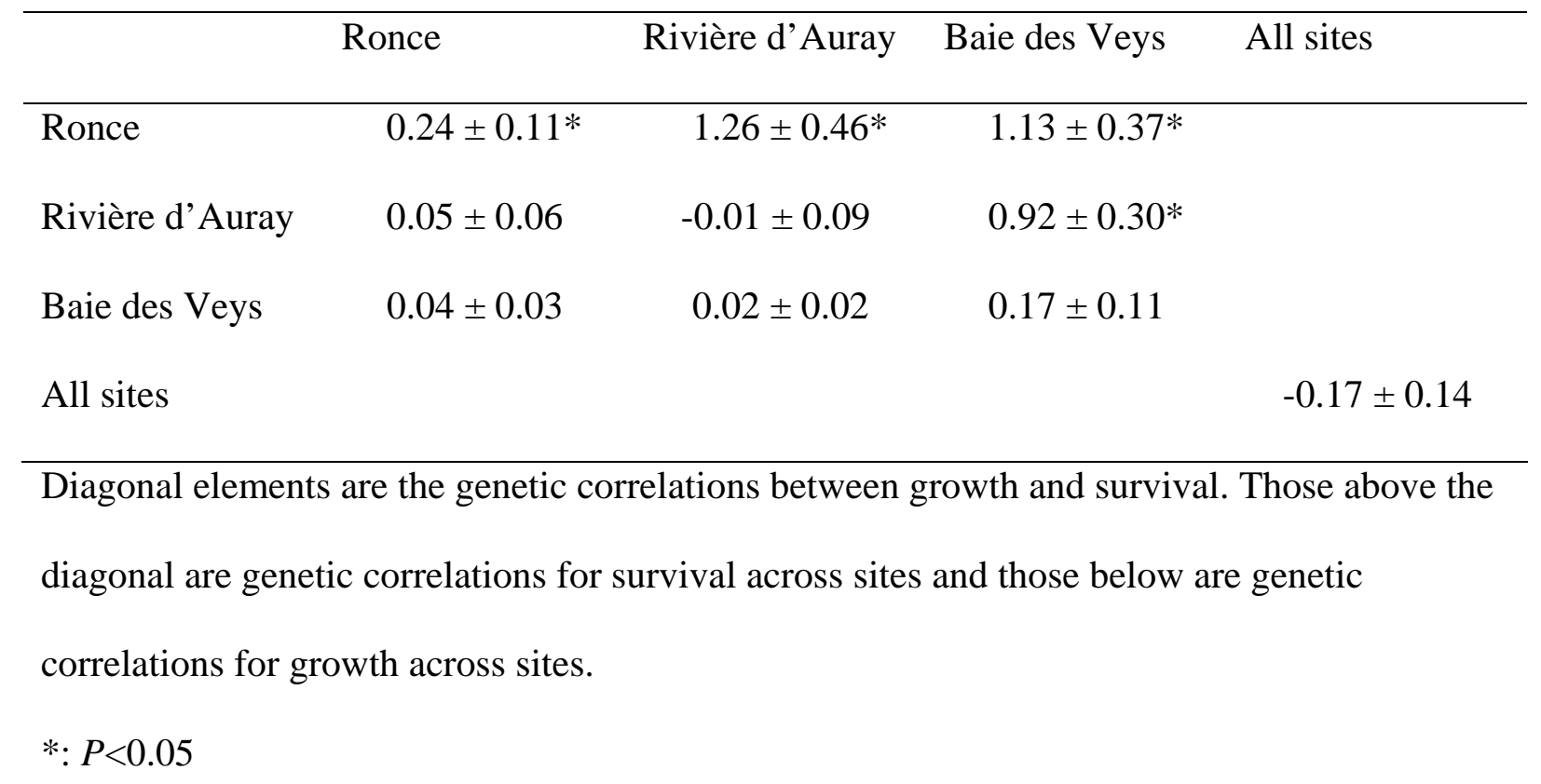

